\title{
Identification of Sickness of Some Selected Garment Factories in Bangladesh and Its Remedial Measures: An Application of Altman's Z-Score Model
}

\author{
Md. Abu Sina*, Md. Nazmul Huda, Hamayet Hossain, Md. Abdus Sabur \\ Department of Accounting \& Information Systems, Islamic University, Kushtia, Bangladesh \\ Email: ^drabusina1970@gmail.com,nazmuliu07@gmail.com, hamayetsir@gmail.com,md.abdussubur@gmail.com
}

How to cite this paper: Sina, Md. A., Huda, Md. N., Hossain, H., \& Sabur, Md. A. (2020). Identification of Sickness of Some Selected Garment Factories in Bangladesh and Its Remedial Measures: An Application of Altman's Z-Score Model. American Journal of Industrial and Business Management, 10, 1823-1838.

https://doi.org/10.4236/ajibm.2020.1012113

Received: November 12, 2020

Accepted: December 20, 2020

Published: December 23, 2020

Copyright () 2020 by author(s) and Scientific Research Publishing Inc. This work is licensed under the Creative Commons Attribution International License (CC BY 4.0).

http://creativecommons.org/licenses/by/4.0/

\begin{abstract}
The study is an attempt to identify sickness of selected garment factories in Bangladesh by the applications of Altman's Z-Score Model and provide a set of remedial measures. Based on the secondary data, two hypotheses are formulated in this regard. Comparative analysis of descriptive statistics, ANOVA, Pearson co-relation coefficient and regression analysis are conducted to reach the objective. Altman's Z-Score found that BHML (1.28) and Generation (0.55) garment factories are in sick zone (Less than 1.81). The garment factory-Style shows that its position is out of sick zone $(2.99<3.16)$ during the period under study. The measurements of Pearson's correlation coefficient of Altman's Z-score associated with each of those 5 (five) are found to be a negative association in most of the cases of the selected garment factories under study which imply the symptoms of sickness tendency for the specified cases. The results of ANOVA-Test for Altman's model related variables of the selected garment factories under study revealed that the sickness symptoms of the sample garment factories are not the same over the period under review. The identified causes of sickness are inefficiency in working capital management, inefficient operations of current assets, underutilization of available resources, the presence of idle capacity, below satisfactory of activity level in terms of productions etc. The remedial measures suggest to providing sufficient working capital, utilize resources properly, reduce idle capacity, ensure acceptable return on equity, reinvest retained earnings, improve operating profit by reducing operating expenses, improve satisfaction level of productions and sales operations etc.
\end{abstract}

\section{Keywords}

Industrial Sickness, Garment Factories, and Altman's Z-Score Model 


\section{Introduction}

In the economy of Bangladesh, readymade garment (RMG) sector plays a vital role and has a remarkable contribution to the national economy. It is noted that about $83 \%$ of total export earnings come from RMG sector. In 2018-2019, export from the garment sector was US\$ 34,133.27 million against the total export of Bangladesh amounting to US\$ 40,535.04 million which was $84.21 \%$ of total export, whereas in 2019-2020 export from the garment sector was US\$27,949.19 million against the total export of Bangladesh US\$ 33,674.09 million, which was $83.00 \%$ of total export that indicates decreasing position. It's due to the impact of pandemic of Covid-19 all over the world. The percentage of export of RMG to total export of Bangladesh is expressed below: Table 1, Table 2, Figure 1.

Table 1. Percentage of export of rmg to total export of bangladesh (In Million US\$).

\begin{tabular}{cccc}
\hline Year & Export of RMG & Total Export of Bangladesh & \% of RMG to Total Export \\
\hline $2013-14$ & $24,491.88$ & $30,186.62$ & 81.13 \\
$2014-15$ & $25,491.40$ & $31,208.94$ & 81.68 \\
$2015-16$ & $28,094.16$ & $34,257.18$ & 82.01 \\
$2016-17$ & $28,149.84$ & $34,655.90$ & 81.23 \\
$2017-18$ & $30,614.76$ & $36,668.17$ & 83.49 \\
$2018-19$ & $34,133.27$ & $40,535.04$ & 84.21 \\
$2019-20$ & $27,949.19$ & $33,674.09$ & 83.00 \\
\hline
\end{tabular}

Source: Website of Export Promotion Bureau, Dhaka. Compiled by BGMEA.

Table 2. Bangladesh's apparel export to world (In Million USD).

\begin{tabular}{cccc}
\hline Year & Woven & Knit & Total \\
\hline $2013-2014$ & $12,442.07$ & $12,049.81$ & $24,491.88$ \\
$2014-2015$ & $13,064.61$ & $12,426.79$ & $25,491.40$ \\
$2015-2016$ & $14,738.74$ & $13,355.42$ & $28,094.16$ \\
$2016-2017$ & $14,392.59$ & $13,757.25$ & $28,149.84$ \\
$2017-2018$ & $15,426.25$ & $15,188.51$ & $30,614.76$ \\
$2018-2019$ & $17,244.73$ & $16,888.54$ & $34,133.27$ \\
$2019-2020$ & $14,041.19$ & $13,908.00$ & $27,949.19$ \\
\hline
\end{tabular}

Source: Export Promotion Bureau, Compiled by BGMEA.

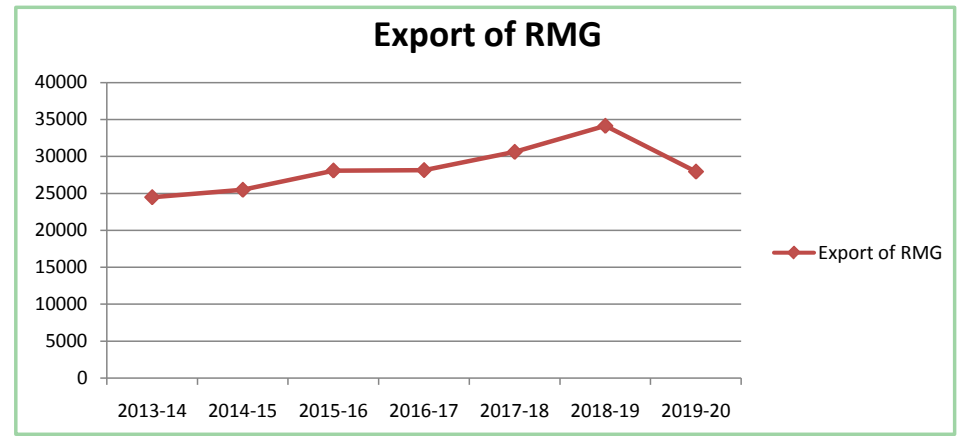

Figure 1. Total export of RMG sector of bangladesh (In Million US\$). Source: Constructed on the Basis of Table 1. 
In the global contest, Bangladesh is the second highest exporter in readymade products after China then Vietnam (Ovi, 2019). About 3.6 million (asiafoundation.org) people are engaged in the garment sector in Bangladesh and out of those approximately $60.20 \%$ are women (Financial Express, 2018). Total scenario of garment factories in Bangladesh is shown in the following table and figure (Table 2 and Figure 1).

Table 3 and Figure 2 present total scenarios of garment factories their trends in Bangladesh. Rubana Haq, President of BGMEA, said that "Now some garment factories are affected with cancellation of order about $\$ 1.5$ billion is lost in this pandemic situation which is impacted 1.2 million in the different factories' employees" (ASIA, 2020).

Table 3. No. of garment factories in bangladesh ranging from 1984-85 to 2018-19.

\begin{tabular}{cc}
\hline YEAR & NUMBER OF GARMENT FACTORIES \\
\hline $1984-85$ & 384 \\
$1994-95$ & 2182 \\
$1999-00$ & 3200 \\
$2004-05$ & 4107 \\
$2009-10$ & 5063 \\
$2010-11$ & 5150 \\
$2011-12$ & 5400 \\
$2012-13$ & 5876 \\
$2013-14$ & 4222 \\
$2014-15$ & 4296 \\
$2015-16$ & 4328 \\
$2016-17$ & 4482 \\
$2017-18$ & 4560 \\
$2018-19$ & 4621 \\
\hline
\end{tabular}

Source: Website of BGMEA.

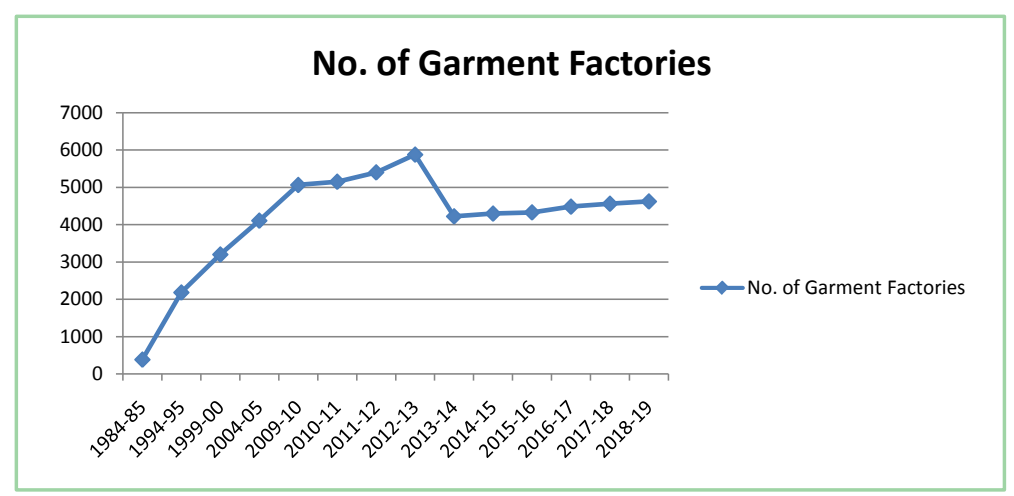

Figure 2. No. of Garment Factories in Bangladesh Ranging from 1984-85 to 2018-19. Source: Constructed on the Basis of Table 3. 
This study is an initiative for identifying the sickness of the garment factories of Bangladesh and providing suggestions to overcome the sickness through Altman's Model.

\section{Objectives of the Study}

The core objective of the study is to identify sickness and to provide remedial measures for removing the sickness of some selected garment factories in Bangladesh. On the other hand, the specific objectives are presented as follows:

1) To clarify the variability of the ratios of the selected garment factories in Bangladesh on the basis of Altman's model;

2) To measure sickness of the garment factories under study through Altman's Model;

3) To identify the causes and impact of sickness derived from Altman's Z-score performance by the selected ratios for the selected factories;

4) To provide some suggestions and recommendations to overcome the problems of the garment industry.

\section{Statement of the Problem}

The scenario of garment sector of Bangladesh is now not in stable position. Financial ratios have the predictive power to identify the financial soundness or failure of a farm. According to Altman's model of predicting financial distress, five ratios namely working capital to total assets; retained earnings to total assets; EBIT to total assets; book value equity to total liabilities and sales to total assets (asset turnover) are able to discriminate between success and failure of farm by calculating the Altman's Z-score based on the above mentioned five ratios. It is noted that the managements of most of the garment factory are not able to hold the stable position, upward trends or positive impact on calculated score of each of the Altman's suggested ratios that are main symptoms of sickness tendency resulting in the miserable situation of the garment sector in Bangladesh. The study is an attempt to identify these adverse impacts on selected garments factories according to this model and to make suggestions to overcome the problems.

\section{Review of Related Literature}

Some reviewed literatures are presented here for identifying research gap as follows:

Chowdhury \& Barua (2009) examined the financial aspects of Z-category companies' shares in Dhaka Stock Exchange by using Z-Score analysis and established the outcome that $90 \%$ of the companies under study were facing financial problem due to weaker management capacity and poor efficiency in operational activities and concluded that most of the company in Bangladesh are not used the applications of Altman's Z-Scores.

Bum (2007) presented a paper which investigates the robustness of Altman's Z-score model. Three aspects of predictability of the Z-Score model are tested: Firstly the significance of the model in term of the prediction horizon, secondly 
the significance of the Z-score model from 1996 to 2000 and lastly the significance of the model for individual industries and concluded that Altman's Z-score model may have partially lost its significance as a bankruptcy prediction measure on two grounds: it is losing its prediction power for long-term prediction, and its accuracy is deteriorating for recent years' data.

Hamid et al. (2016) stated that Non-Bank Financial Institutions (NBFIs) are rapidly growing in Bangladesh which play a vital role in the economy. This study attempts to predict the financial health of 15 publicly traded NBFIs of Bangladesh over five years ranging from 2011 to 2015 using Altman's Z-Score Model (1965). The results show that most of the sampled NBFIs are in "Distress" zone, fail to attain the minimum score and lying on the bankruptcy level. The study suggests the stakeholders, including regulatory authorities and researchers to be more watchful of the operations of NBFIs.

Bushra \& Mishra (2015) stated that the performance of automobile industry can be used as an indicator to assess the economic strength of any country. This paper attempts to study the financial health of automobile industry in India using Altman's Z-Score model of the select automobile companies listed in Bombay Stock Exchange (BSE) for last five years i.e. 2010 to 2014 and revealed that Z-Scores for all the select automobile companies were more than 2.9 during the study period except Tata Motors which according to the study had Z-Score between 1.8 and 2.9 during the year 2010 and 2011. So all are financially sound, away from bankruptcy zone and are safe to invest.

Kertapati et al. (2010) stated that company's performance is important to management, shareholders, government, customers, suppliers and other stakeholders directly or indirectly. Financial ratio analysis is the most popular tools to measure the performance. The purpose of this paper is to find out financial performance using of multiple discriminant analysis using samples from the finance sector from Bursa Malaysia and shows that 5 variables are significant in the model development which are Net Working Capital Ratio, Return on Asset, Operating Profit Margin, Total Asset Turnover, and Sales to Fixed Asset Ratio.

Chakraborty (2017) explained Risk management activity integrates recognition of risk, risk assessment, developing strategies, and mitigation of risk using managerial resources. The future of banking will undoubtedly rest on risk management dynamics. The objective of the paper is to make an attempt to identify the risks faced by the banking industry and the process of risk management. There is a major dearth of literature that examines the applicability of Altman's Z" Score model to forecasting banking failures. Z-Score model is an accurate forecaster of failure up to two years prior to distress.

On the basis of the above reviews, there is no comprehensive research work on sickness identification and its remedial measures of ready-made garment factories of Bangladesh. There lies a research gap. For fulfilling this research gap the authors have chosen the topic "Identification of sickness of some selected garment factories in Bangladesh and its remedial measures: An application of Altman's Z-Score Model" as research work. 


\section{Concept of the Important Terms}

Concepts of the different important terms are furnished below:

Altman Z-Score: The Altman Z-Score is a formula of 5 basic financial ratios to help determine the financial health of a company. In particular, it is a probabilistic model to screen for bankruptcy risk of a company (Faulkenberry, 2019).

The Altman Z-Score Formula

The original formula was created for publicly traded manufacturing companies.

$$
\text { Z-Score }=1.2 A+1.4 B+3.3 C+0.6 D+1.0 E
$$

where:

$A=$ Working Capital (Current Assets - Current Liabilities)/Total Assets (Measures liquidity of firm)

$B=$ Retained Earnings/Total Assets (Measures accumulated profits compared to assets)

$C=$ Earnings Before Interest \& Taxes (EBIT)/Total Assets (Measures how much profit the firms' assets are producing)

$D=$ Market Value of Equity (Mkt. Cap. + Preferred Stock)/Total Liabilities (Compares the company's value versus its liabilities)

$E=$ Sales/Total Assets (Efficiency ratio - measures how much the company's assets are producing in sales).

\section{Z-Score Results}

Z-Score $<1.81$ represents a company is in distress (Sick).

Z-Score in between 1.81 and 2.99 represents the "caution" zone (Going to be sick).

$2.99<\mathrm{Z}$-Score represents a company that is in a safe zone (Faulkenberry, 2019).

Multiple Discriminant Analysis: Multiple Discriminant Analysis (MDA) is a multivariate dimensionality reduction technique. It has been used to predict signals as diverse as neural memory traces and corporate failure. In 1968, Edward Altman advanced upon Beaver's work by incorporating four more variables into the model to give an overall more precise prediction of manufacturing corporate failure. Altman classifies the companies into two mutually exclusive groups; bankrupt and non-bankrupt (Altman, 1968).

The original Altman's model took the following form:

$$
Z=0.012 X_{1}+0.014 X_{2}+0.033 X_{3}+0.006 X_{4}+0.999 X_{5}
$$

where:

$X_{1}=$ Working capital/Total assets (a measure of liquidity);

$X_{2}=$ Retained earnings/Total assets (a measure of reinvested earnings and past profitability);

$X_{3}=$ Earnings before interest and taxes/Total assets (a measure of profitability);

$X_{4}=$ Market value of equity/Book value of Total liabilities (a measure of financial structure or leverage); and 
$X_{5}=$ Sales/Total assets (a measure of assets efficiency).

Standard: Above 2.99, Suspect Zone: 1.81 - 2.99, Sick Zone: 0 - 1.81 (Mohapatra, 2012).

Working Capital (WC): Working capital is money that's available to a company for its day-to-day operations. Simply put, working capital indicates a company's operating liquidity and efficiency. A company's working capital reflects a host of company activities, including cash, inventory, accounts receivable, accounts payable, and the portion of debt due within one year (as well as any other short-term accounts (Siegel \& Hwang, 2020).

It is the difference between current assets and current liabilities. It may be in positive or negative which is a measure of a company's liquidity, operational efficiency and its short-term financial health (Investopedia).

Total Assets: Total assets represent all the money that the business currently has, along with any other type of asset that brings value to the company. This includes physical assets like equipment and property as well as more intangible assets like a patent or copyright. It can also include the potential for profit, such as investments and accounts receivable that have not yet been paid. Total assets will equal total claims, not necessarily because of debt but because of the ownership issues involved (Lacoma, 2019).

Retained Earnings (RE): Retained Earnings (RE): are earnings not distributed to shareholders, instead reinvested in the firm. The RE to TA ratio measures the degree of financing of total assets via surplus profits. It also measures the degree of leverage of a company. The ratio measures cumulative profitability of a firm and indicates the firm's earning power as well as age (Altman, 2000).

Retained earnings (RE) is the amount of net income left over for the business after it has paid out dividends to its shareholders. A business generates earnings that can be positive (profits) or negative (losses). Formula of retained earnings is (Kenton, 2019):

$$
\mathrm{RE}=\mathrm{BP}+\text { Net Income }(\text { or Loss })-\mathrm{C}-\mathrm{S}
$$

where,

$$
\begin{aligned}
& \mathrm{BP}=\text { Beginning Period RE } \\
& \mathrm{C}=\text { Cash dividends } \\
& \mathrm{S}=\text { Stock dividends }
\end{aligned}
$$

Earnings before Interest and Taxes (EBIT): refer to the earnings generated from the operating activities of the firm. The ratio EBIT/TA measures the efficiency of assets in generating profits. Low EBIT/TA ratio indicates that the firm is not using the assets efficiently in generating profits. This ratio estimates the cash supply available for allocation to the creditors, government and shareholders. This ratio is believed to be extremely appropriate for investigating firm bankruptcy because the ultimate existence of the company depends on earning power (Altman, 1968).

Liabilities: Liabilities is the measuring of both the long and current term, while equity is found to be the market value of all the shares of common, preferred and stock. This measure demonstrates how much the firm's assets might 
decline in value before the assets become lower than liabilities and the company becomes bankrupt (Altman, 2000).

Asset Turnover: The asset turnover ratio measures the value of a company's sales or revenues relative to the value of its assets. The asset turnover ratio can be used as an indicator of the efficiency with which a company is using its assets to generate revenue (Hayes, 2019).

Readymade Garment: Readymade garment refers to ready to wear garments made following the cut, make, trim (CMT) manufacturing process of cutting fabric, making with accessories, and trimming, before being ironed, packed and exported (Islam, 2014).

Range: Range is the simplest method of studying variation. It is defined as the difference between the value of the smallest observation and the value of the largest observation included in the distribution. Symbolically, it is defined as, $\mathrm{R}$ $=\mathrm{L}-\mathrm{R}$ where $\mathrm{R}=$ range, $\mathrm{L}=$ Largest value, $\mathrm{R}=$ Smallest value (Gupta \& Gupta, 2007).

Standard Deviation: The variance is the measure of the average squared distance between mean and each item of the population. The positive squared root of the variance measures of dispersion in the same units as the original data rather than in the squared units of the variance (Levin \& Rubin, 2019).

Correlation: Correlation Analysis is a statistical technique used to indicate the nature and degree of relationship existing between one variable and the other(s) (Gupta \& Gupta, 2007).

Multiple Regressions: Multiple-regression is a statistical procedure in which a dependent variable $(Y)$ is modeled as a function of more than one variable $\left(X_{1}, X_{2}, X_{3}, \cdots, X_{n}\right)$. The population multiple-regression model may be written as:

$$
Y=\beta_{0}+\beta_{1} X_{1}+\beta_{2} X_{2}+\beta_{3} X_{3}+\cdots+\beta_{k} X_{k}+\varepsilon
$$

where $\left(\beta_{0}\right)$ is the intercept and other $\beta_{i}$ 's are the slope terms associated with the respective independent variables. In this model, $\varepsilon$ represents the population error term, which is the difference between the actual $Y$ and that predicted by the regression model $(Y)$. The ordinary least-squares (OLS) criterion for the best multiple-regression model is that the sum of squares of all the terms is minimized (Gupta \& Gupta, 2007).

Variance Inflationary Factor: The application of multiple regressions involves the possible multi-co-linearity of the explanatory variables. This condition refers to situations in which some of the explanatory variables are highly correlated with each other. In such cases, the values of the regression coefficients for the correlated variables may fluctuate drastically, depending on which variables are included in the model. One method of measuring co-linearity uses the variance inflationary factor (VIF) for each explanatory variable. This VIF is defined as VIF $=\left\{1 /\left(1-R^{2}\right)\right\}$, where, $R^{2}$ represents the coefficient of multiple determination of explanatory variable $X$ with all other $x$ variables. If a set of explanatory variables are uncorrelated, then VIF will be equal to 1 . If the set were highly Inter-correlated, then VIF might even exceed 10. However, other re- 
searchers suggest a more conservative criterion that would employ alternative to least-squares regression if the maximum VIF were not to exceed 5 (Lind, Marchal, \& Mason, 2002).

\section{Research Methodology}

Three garment factories are selected as sample like Stylecraft Limited, BHML Sweaters Limited and Generation Next Fashion Limited purposively on the basis of stratified random sampling method. The study is conducted through secondary data. This study has covered the period 2014-15 to 2019-20 (six years). The main sources of collected information are annual reports, audits reports of the selected garment factories, Articles from online published journals, website of BGMEA, Export Promotion Bureau, Ministry of Finance, Bangladesh Bureau of Statistics (BBS) and CPD (Central for Policy Dialogue). The collected information has been compiled in ordered to convert into the selected ratios and are analyzed by using related statistical tools and techniques with the help of SPSS Version-22. The historical background of three selected garment factories under review in Dhaka has been exposed in brief as below:

1) Stylecraft Limited: Stylecraft Limited is one of the pioneer Ready Made Garment Manufacturers in Bangladesh that recognized as "Made in Bangladesh" tag as a prestigious brand across the globe was established in 1983 as a Public Limited Company under the Companies Act 1913 and listed in Dhaka Stock Exchange Limited in the same year by Mr. M. Shamsur Rahman which was in Monipuripara, Tejgoan. The capacity of production has grown rapidly ever since with the help of latest machineries \& equipment's, efficient workforce and long experience. Last year, Stylecraft Limited has exported USD 41.78 million to the world market. New art factory in Gazipur is equipped with the latest machineries and technologies and meets all health and safety guidelines in relation to fire and safety regulations, lighting and emergency procedures. Now, Stylecraft Limited has 32 product lines and 3,00,000 square feet utilized work area where 5250 employees were engaged and the monthly production capacity $11,50,000$ (Source: Annual report 2018-2019).

2) BHML Sweaters Limited: BHML Sweaters Limited was established in 2008 for producing $100 \%$ export-oriented sweaters in a rented factory. The registration number is 4584 as a member in BGMEA. The number of workers engaged in the factory is 1200 and which has 350 sweating machines having production capacity of 50,000 dozens per year (Source: Financial Statements 2018-2019 and BGMEA).

3) Generation Next Fashion Limited: Generation Next Fashion Limited (GNFL) was started its business journey in 2004 with an authorized capital of BDT 500.00 million and paid up capital of BDT 47.20 million to carry out knitting, Dying, and various types of readymade garments manufacturing on the basis of international standard and design. Its launched commercial operation of $100 \%$ export-oriented textile and Apparel Company and produces composite knit fabrics and various types of readymade garments from 2006. Now a day the 
paid up capital of the company is 4949.75 million. The main products are T-shirts, polo shirts, night wear, and hoody jackets etc. which are exported in USA, UK, Canada, Europe and Australia (Source: Annual report 2018-2019).

\section{Hypothesis of the Study}

Two hypotheses are formulated for this study on the basis of the purpose of the research work as follows:

$\mathrm{H}_{0}: 1$ There is no significant difference among the selected garment factories relating to each of the ratios of Altman's model over the period under study.

$\mathrm{H}_{0}: 2$ There is no significant positive impact on the performance (Z-Score) of the ratios associated with Altman's model for the selected garment factories over the period under study.

\section{Analysis and Interpretation}

Comparative analysis of descriptive statistics of the sample garment factories regarding the variables of Altman's model is given below.

Table 4. Comparative analysis of descriptive statistics of the sample garment factories regarding the variables of altman's model.

\begin{tabular}{|c|c|c|c|c|}
\hline \multirow{2}{*}{$\begin{array}{l}\text { Measurement } \\
\text { Tools }\end{array}$} & \multicolumn{4}{|c|}{ Working capital/Total assets $\left(X_{1}\right)$} \\
\hline & Style & BSML & Generation & Average \\
\hline Range & 0.18 & 0.37 & 0.05 & 0.51 \\
\hline Mean & -0.09 & 0.16 & 0.27 & 0.11 \\
\hline \multirow[t]{2}{*}{ Std. Deviation } & 0.07 & 0.15 & 0.02 & 0.18 \\
\hline & \multicolumn{4}{|c|}{ Retained earnings/ Total assets $\left(X_{2}\right)$} \\
\hline Range & 0.06 & 0.24 & 0.08 & 0.65 \\
\hline Mean & 0.21 & 0.57 & 0.08 & 0.28 \\
\hline \multirow[t]{2}{*}{ Std. Deviation } & 0.02 & 0.09 & 0.03 & 0.22 \\
\hline & \multicolumn{4}{|c|}{ Earnings before interest and taxes/Total assets $\left(X_{3}\right)$} \\
\hline Range & 0.04 & 0.29 & 0.05 & 0.29 \\
\hline Mean & 0.08 & 0.08 & 0.09 & 0.08 \\
\hline \multirow[t]{2}{*}{ Std. Deviation } & 0.02 & 0.10 & 0.02 & 0.06 \\
\hline & \multicolumn{4}{|c|}{ Market value of equity/Book value of Total liabilities $\left(X_{4}\right)$} \\
\hline Range & 0.10 & 2.11 & 3.22 & 4.99 \\
\hline Mean & 0.27 & 1.85 & 4.21 & 2.11 \\
\hline \multirow[t]{2}{*}{ Std. Deviation } & 0.04 & 0.77 & 1.18 & 1.83 \\
\hline & \multicolumn{4}{|c|}{ Sales/Total assets $\left(X_{5}\right)$} \\
\hline Range & 1.40 & 3.26 & 0.14 & 3.85 \\
\hline Mean & 3.16 & 1.26 & 0.52 & 1.64 \\
\hline \multirow[t]{2}{*}{ Std. Deviation } & 0.65 & 1.17 & 0.05 & 1.36 \\
\hline & \multicolumn{4}{|c|}{ Altman's Z-Score } \\
\hline Range & 1.39 & 3.28 & 0.11 & 3.84 \\
\hline Mean & 3.16 & 1.28 & 0.55 & 1.66 \\
\hline Std. Deviation & 0.65 & 1.18 & 0.04 & 1.35 \\
\hline
\end{tabular}

Source: Compiled on the basis of annual reports ranging 2013-2014 to 2018-2019. 
Table 4 shows comparative analysis of descriptive statistics of the sample garment factories regarding the variables of Altman's model defined as Working capital/Total assets $\left(X_{1}\right)$; Retained earnings/Total assets $\left(X_{2}\right)$; Earnings before interest and taxes/Total assets $\left(X_{3}\right)$; Market value of equity/Book value of Total liabilities $\left(X_{4}\right)$; Sales/Total assets $\left(X_{5}\right)$ and Altman's Z-Score each of which is measured by the tools range, mean and standard deviation. The higher the range and standard deviation are indicating less stability of the concern variable; whereas the mean values of the ratios ascertain the performance of the garment factories under study. The mean of Altman's Z-Score found to be below standard for BSML (1.28) and Generation (0.55) garment factories that are within the Sick Zone $(0-1.81)$ as suggested by Altman's Z-Score. The garment factory Style (Mean 3.16) shows that it is in the out of sick zone [More than 2.99 (standard)] during the period under study.

\section{Test of Hypotheses}

1) $\mathrm{H}_{0}: 1$ There is no significant difference among the selected garment factories relating to each of the ratios of Altman's model over the period under study.

Table 5 indicates the results of ANOVA for Altman's model related variables of the selected garment factories under study where every calculated value of F-ratio $X_{1}(20.57) ; X_{2}(126.59) ; X_{3}(3.64) ; X_{4}(35.38) ; X_{5}(18.47)$ and $Z(17.94)$ is greater than that of the critical value of $F=\mathbf{3 . 6 8}$ at 5 percent level of significance except $X_{3}$ (3.64). So the null hypothesis is rejected for all the cases except $X_{3}$ and it is concluded that there is a significant difference among the selected garment factories for each of the variables but there is no significant difference in the variable $\left(X_{3}\right)$ under study period.

2) $\mathrm{H}_{0}: 2$ There is no significant positive impact on the performance (Z-Score) of the ratios associated with Altman's model for the selected garment factories over the period under study.

Table 6 describes the measurements of Pearson correlation co-efficient of Altman's Z-score with each of that variable of selected garment factories under study. The variable $X_{1}$ is found significant positive impact on performance (Alman's Z-Score) in Style Garments Limited $\left(0.845^{*}\right)$ whereas for other factories it is in negative position. The positive impact of $X_{2}$ variable on the performance (Altman's Z-score) is found to be 0.758 (BHML) and 0.076 (Average) but it in negative position by -0.781 and -0.690 in Style and Generation respectively. The variable $X_{3}$ revealed positive significant impact on performance for all of the garment factories except Generation $(-0.690)$. The analyzed variable $X_{4}$ is negatively significant association with the score except BHML. The variable $X_{5}$ has the positive significant impact on performance for each of the garment factories under review. The negative correlation indicates the sickness symptom of the concerned garment factory.

\section{Overall Impact: Multiple Regressions Analysis}

Table 7 shows the model summary of the selected garment factories where the 
dependent variable is performance (Altman's Z-Score) and independent variables are Working capital/Total assets $\left(X_{1}\right)$, Retained earnings/Total assets $\left(X_{2}\right)$, Earnings before interest and taxes/Total assets $\left(X_{3}\right)$ and Market value of equity/Book value of Total liabilities $\left(X_{4}\right)$. The variable Sales/Total asset $\left(X_{5}\right)$ is excluded from regression analysis due to multi-co-linearity problem. The multiple R, R-Square, Adjusted R-Square and Std. Error is found to 94.4 percent; 89.2 percent 85.8 percent and 0.507 respectively indicating good fit of the model. The $\mathrm{R}$-Square value is 89.2 indicated $89.2 \%$ variance is explained by the predictors included in the model.

Table 8 shows the regression analysis of the identified variables of selected sample garment factories where the variable $X_{3}$ (Earnings before interest and taxes/Total assets) has the positive significant impact on performance (Altman's Z-Score) by coefficient amounted to $13.518^{\star}$ at 1 percent level. The rest of the cases have the negative significant impact on the performance (Altman's Z-Score).

Table 5. ANOVA-single factor for each of the ratios of Altman's model over the period under review.

\begin{tabular}{|c|c|c|c|c|c|c|}
\hline \multirow{2}{*}{ Variables } & \multicolumn{3}{|c|}{ Sums Square } & \multicolumn{2}{|c|}{ Mean Sums Square } & \multirow{2}{*}{ F-ratios } \\
\hline & 1 & 2 & 3 & 1 & 2 & \\
\hline$X_{1}$ & 0.38 & 0.14 & 0.52 & 0.19 & 0.01 & $20.57^{* *}$ \\
\hline$X_{2}$ & 0.78 & 0.5 & 0.83 & 0.39 & 0.003 & $126.59^{* *}$ \\
\hline$X_{3}$ & 0.0002 & 0.0538 & 0.053 & 0.0001 & 0.0035 & 3.64 \\
\hline$X_{4}$ & 47.01 & 9.96 & 56.96 & 23.51 & 0.66 & $35.38^{* *}$ \\
\hline$X_{5}$ & 22.22 & 9.02 & 31.24 & 11.11 & 0.6 & $18.47^{\star *}$ \\
\hline$Z$ & 21.75 & 9.09 & 30.84 & 10.87 & 0.61 & $17.94^{* *}$ \\
\hline
\end{tabular}

Source: Compiled from annual reports from 2013-2014 to 2018-2019; 1 = Between Groups with degree of freedom 2; 2 = Within Groups with degree of freedom 15; 3 = Total with degree of freedom 15; The Table value of $\mathrm{F}$ at $5 \%$ level of significance $=3.68$ indicated by ${ }^{* *}$.

Table 6. Correlation co-efficient of each the Variables Associated with Altman's Z-Score of the selected garment factories.

\begin{tabular}{cccccc}
\hline \multirow{2}{*}{$\begin{array}{c}\text { Garment } \\
\text { Factory }\end{array}$} & $X_{1}$ & $X_{2}$ & $X_{3}$ Variables of Altman's Model & $X_{4}$ & $X_{5}$ \\
\cline { 2 - 5 } Style & $0.845^{*}$ & -0.781 & $0.888^{*}$ & $-0.900^{*}$ & $1.000^{* *}$ \\
BHML & -0.494 & 0.758 & $0.978^{* *}$ & $0.841^{*}$ & $1.000^{* *}$ \\
Generation & -0.129 & -0.690 & -0.188 & $-0.820^{*}$ & $0.992^{* *}$ \\
Average & $-0.776^{* *}$ & 0.076 & $0.479^{*}$ & $-0.629^{* *}$ & $1.000^{* *}$ \\
\hline
\end{tabular}

Source: Compiled from annual reports from 2013-2014 to 2018-2019; N = 6 for Style, BHML \& Generation; $\mathrm{N}=18$ for Sample; ${ }^{* *}$ Correlation is significant at the 0.01 level (2-tailed); and ${ }^{\star}$ Correlation is significant at the 0.05 level (2-tailed). 
Table 7. Model summery of the selected garment factories.

\begin{tabular}{cccc}
\hline $\mathbf{R}$ & R Square & Adjusted R Square & Std. Error \\
\hline 0.944 & 0.892 & 0.858 & 0.507 \\
\hline
\end{tabular}

Source: Compiled from annual reports from 2013-2014; Predictors: (Constant), Working capital/Total assets $\left(X_{1}\right)$, Retained earnings/Total assets $\left(X_{2}\right)$, Earnings before interest and taxes/Total assets $\left(X_{3}\right)$ and Market value of equity/Book value of Total liabilities $\left(X_{4}\right)$.

Table 8. Regression coefficients of selected variables of the factories.

\begin{tabular}{ccc}
\hline Parameters & Coefficients of Parameters & \multirow{2}{*}{ VIF } \\
\cline { 1 - 2 } (Constant) & $1.974^{*}$ & \\
\hline Working capital/Total assets $\left(X_{1}\right)$ & $-2.654^{* *}$ & 2.045 \\
Retained earnings/ Total assets $\left(X_{2}\right)$ & -0.847 & 1.109 \\
Earnings before interest and taxes/Total assets $\left(X_{3}\right)$ & $13.518^{*}$ & 1.261 \\
Market value of equity/Book value of Total liabilities $\left(X_{4}\right)$ & $-0.419^{*}$ & 2.273 \\
\hline
\end{tabular}

Source: Compiled from annual reports from 2013-2014; Dependent Variable: Altman's Z-Score, $\mathrm{N}=18$, , **, significance level at $1 \%$, and $5 \%$ consecutively.

\section{Result and Discussion}

The mean of Altman's Z-Score was found to be below standard for BSML (1.28) and Generation (0.55) garment factories that are in the Sick Zone $(0-1.81)$ as calculated by Altman Model. The garment factory-style shows the mean of Altman's Z-Score 3.16 and it reflects that it is in the out of sick zone (Standard: 2.99) during the period under study. The mean of the variables of Altman's model defined as Working capital/Total assets $\left(X_{1}\right)$; Retained earnings/Total assets $\left(X_{2}\right)$; Earnings before interest and taxes/Total assets $\left(X_{3}\right)$; Market value of equity/Book value of Total liabilities $\left(X_{4}\right)$; Sales/Total assets $\left(X_{5}\right)$ and Altman's Z-Score are found to be lower than that of the average or below of the standard throughout most of the cases, resulting in the sickness symptoms of the garment factories.

The results of ANOVA-Test for Altman's model related variables of the selected garment factories under study revealed that the mean performance is varied significantly. Thus the sickness symptoms of the sample garment factories are not the same over the period under review.

The measurements of Pearson's correlation coefficient of Altman's Z-score associated with each of those 5 (five) are found to be negative association in most of the cases of the selected garment factories under study which imply the symptoms of sickness tendency for the specified cases.

The regression analysis founds the overall negative impacts on performance (the Altman's Z-Score) in the ratios: working capital/total assets, retained earnings/total assets and market value of equity/book value of total liabilities. It shows tendency of sickness of the garment factories.

On the basis of analysis, interpretation and findings the identified causes of sickness have been furnished below: 
1) Altman's Model identifies low working capital turnover of the factories under study leads to inefficient operations of current assets. So it shows that the working capital management is not efficient and the working capital utilization is not efficiently done by the selected garment factories.

2) The model founds inefficient management and deployments of total asset due to underutilization of available resources and the presence of idle capacity of the selected garment factories under study.

3) The score shows low market book value ratios of the selected garment factories indicate that the return on equity capital is not satisfactory.

4) The study shows that the share of reinvesting earnings of the factories is in negative position. It reveals that there is a negative impact of earnings on overall performance of the selected garment factories over the study period. So it focuses that the factories investment more in total assets and earnings of profits are not sufficient.

5) The low earnings before interest and taxes to total assets are the causes of sickness of the selected factories.

6) The model founds below satisfactory of activity level in terms of productions and sales that lead to sickness tendency of the selected garment factories.

\section{Conclusions and Recommendations}

The Altman's Z-Score Model identifies sickness of the garment factories along with its causes. The result focuses that BSML and Generation are in sick zone and Style is in out of sick zone. It is also found that the managements of the garment factories are not capable enough to hold the stable position of ascending trends of the ratios that could be helpful to provide positive impact on the performance. To uphold the trends of the ratios and to reduce the sickness of the garment sector in Bangladesh, some suggestions are recommended as follows:

1) The management should be efficient in working capital management and utilization of the funds. Sufficient money should be available for mitigating day to day operations;

2) If current asset management becomes efficient, working capital will be increased. So, the management should increase working capital through efficient operations of current assets;

3) All the available resources should be utilized more efficiently and effectively to maximize the profit as well as wealth;

4) The idle capacity of the machinery should be minimized at a reasonable extend;

5) The rate of earnings before interest and taxes (EBIT) should be increased by reducing operating expenses;

6) For expanding business and gearing up the earnings retained earnings should be reinvested and;

7) The level of satisfaction regarding productions and sales operations should be improved. 


\section{Limitations of the Study}

There are some limitations of the study as follows:

1) This study is based on secondary data that do not reflect the perceived situation of the garment industries of Bangladesh.

2) Only Z-scores model is used to measure the situations of the selected garment factories without comparing, considering other measurement tools such as Balance Score Card, Economic Value Added, Market Value Added, DuPont analysis, etc.

3) It does not compare among the large number of factories within the countries or abroad due to unavailability of accurate data.

\section{Recommendations for Further Research}

1) The study can be undertaken with primary as well as secondary data.

2) To get better result more statistical tools with Z-score model may be used.

3) The study may be expanded to its comparison taking more sample garment factories within the countries and abroad.

\section{Conflicts of Interest}

The authors declare no conflicts of interest regarding the publication of this paper.

\section{References}

Altman, E. I. (1968). Financial Ratios, Discriminant Analysis and the Prediction of Corporate Bankruptcy. The Journal of Finance, 23, 589-609. https://doi.org/10.1111/j.1540-6261.1968.tb00843.x

Altman, E. I. (2000). Predicting Financial Distress of Companies: Revisiting the Z-Score and Zeta Models. https://ideas.repec.org/h/elg/eechap/14545 17.html

ASIA (2020). Coronavirus: Bangladesh's Garment Industry Risks Collapse. https://www.dw.com/en/coronavirus-bangladeshs-garment-industry-risks-collapse/a-5 $\underline{2917410}$

Bum, J. K. (2007). Bankruptcy Prediction: Book Value or Market Value? 2007 APRIA Annual Meeting.

Bushra, M., \& Mishra, K. (2015). Efficacy of Altman's z-Score to Predict Financial Unassailability: A Multiple Discriminant Analysis (MDA) of Select Automobile Companies in India. Golden Research Thoughts, 4.

https://thejournalofbusiness.org/index.php/site/article/view/733/0

Chakraborty, S. A. (2017). Z-Scores: An Effective Way of Analysing Banks Risks. Asia Pacific Journal of Research, 1. http://www.apjor.com

Chowdhury, A., \& Barua, S. (2009). Rationalities of z-Category Shares in Dhaka Stock Exchange: Are They in Financial Distress Risk? BRAC University Journal, 6, 45-58.

Faulkenberry, K. (2019). Altman Z-Score Formula-Screening for Bankruptcy Risk. https://www.arborinvestmentplanner.com/altman-z-score-formula

Financial Express, 04/03/2018.

Gupta, S. P., \& Gupta, M. P. (2007). Business Statistics (14th Enlarged ed.). New Delhi: 
Sultan Chand \& Sons.

Hamid, T., Akhter, F., \& Rab, N. B. (2016). Prediction of Financial Distress of Non-Bank Financial Institutions of Bangladesh Using Altman's Z-Score Model. International Journal of Business and Management, 11, 261.

https://doi.org/10.5539/ijbm.v11n12p261

Hayes, A. (2019). What Is the Asset Turnover Ratio?

https://www.investopedia.com/terms/a/assetturnover.asp

Islam, Md. S. (2014). Informal Labor Incentives and Firm Performance: A Case Study of RMG Industry in Bangladesh. International Business and Management, 8, 19-27.

Kenton, W. (2019). Retained Earnings. https://www.investopedia.com/terms/r

Kertapati, M. R., Dali, N. R. S. B. M., \& Zulkifli, A. H. (2010). Evaluating Company’s Performances Using Multiple Discriminant Analysis. American Journal of Finance and Accounting, 2, 143-154. https://doi.org/10.1504/AJFA.2010.037060

Lacoma, T. (2019). https://smallbusiness.chron.com

Levin, R. I., \& Rubin, D. S. (2019). Statistics for Management. New Delhi: Prentice Hall.

Lind. D. A., Marchal, W. G., \& Mason, R. D. (2002). Statistical Techniques in Business \& Economics. New York: The McGraw-Hill Companies, Inc.

Mohapatra, A. K. D. (2012). International Accounting (2nd ed., pp. 196-199). New Delhi: PHI Learning Private Limited.

Ovi, I. H. (2019). RMG Global Market Share: Bangladesh Loses as Vietnam Gains. http://www.dhakatribune.com

Siegel, R., \& Hwang, R. (2020). Working Capital. https://investinganswers.com

\section{Websites}

https://www.dhakatribune.com/business/economy/2019/08/04/rmg-global-market-sharebangladesh-loses-as-vietnam-gains

http://www.epb.gov.bd/site/page/7bd7d4d7-cdba-4da3-8b10-f40da01e49b6/MarketAccess -Facilities

https://mof.portal.gov.bd/site/page/28ba57f5-59ff-4426-970a-bf014242179e/Bangladesh-E conomic-Review

http://rmg-study.cpd.org.bd/cpd-rmg-study-2018-concluded-with-recommendations-for -sustainability-of-the-rmg-sector/

https://www.academia.edu/2070576/Evaluating Companys Performances Using Multip le Discriminant Analysis?auto = download\&email work card = download-paper

http://stylecraftltd.com/investors/

https://www.gnf-bd.com/annual-report.html

http://www.bgmea.com.bd/member/memberlist/580

https://courses.lumenlearning.com/boundless-finance/chapter/the-dupont-equation-roeroa-and-growth

https://www.accountingtools.com/articles/2017/5/15/total-assets

https://www.wto.org/english/res e/statis e/wts2020 e/wts20 toc e.htm

https://asiafoundation.org/slideshow/bangladeshs-garment-workers/

https://www.investopedia.com/terms/w/workingcapital.asp

http://www.dhakatribune.com/ 